\title{
Practical disinfection chemicals for fishing and crayfishing gear against crayfish plague transfer
}

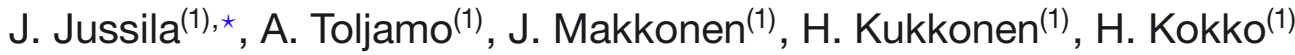 \\ Received November 4, 2013 \\ Revised January 9, 2014 \\ Accepted January 10, 2014
}

Key-words:

Aphanomyces

astaci,

oxidative

inactivation, peracetic acid, disease spreading

\section{ABSTRACT}

We tested four commercial disinfectants against crayfish plague (Aphanomyces astaci) spores in both aquatic solutions and with material mimicking fishing and crayfishing gear, e.g. traps, ropes, mesh, etc. The tested disinfectants were Proxitane ${ }^{\circledR} 5: 14$, Proxitane ${ }^{\circledR} 12: 20$, Wofasteril ${ }^{\circledR} E 400$, Virkon ${ }^{\circledR} S$ and hydrogen peroxide. The effects of the chemicals were initially tested in liquid zoospore cultures and the effective concentrations were then further tested using clean and dirty model materials (PP sheet, nylon rope, cotton fabric) contaminated with $A$. astaci spore solutions. The disinfectants effective against infective crayfish plague spores with both clean and dirty model materials were Proxinate ${ }^{\circledR} 5: 14$ (effective concentration was $30 \mathrm{mg} \cdot \mathrm{L}^{-1}$ of PAA) and Virkon ${ }^{\circledR} S\left(3 \mathrm{~g} \cdot \mathrm{L}^{-1}\right)$, while Proxinate ${ }^{\circledR} 12: 20\left(10 \mathrm{mg} \cdot \mathrm{L}^{-1}\right.$ of PAA) and Wofasteril ${ }^{\circledR} \mathrm{E} 400$ (30 $\mathrm{mg} \cdot \mathrm{L}^{-1}$ of PAA) worked only with clean model materials. Hydrogen peroxide was not effective in the tested concentrations and conditions. Based on the results, the disinfectants most suitable for the fishing and crayfishing gear disinfection would be Proxitane ${ }^{\circledR} 5: 14$ and Virkon ${ }^{\circledR} S$, with the condition that all the gear should be thoroughly cleaned of organic matter to ensure inactivation of $A$. astaci spores.

RÉSUMÉ

Produits chimiques de désinfection du matériel de pêche et de manipulation des écrevisses contre la propagation de la peste de l'écrevisse

Mots-clés : Aphanomyces astaci, inactivation oxydative, acide peracétique, propagation de maladie
Nous avons testé quatre désinfectants commerciaux contre les spores de la peste des écrevisses (Aphanomyces astaci) à la fois dans les solutions aquatiques et avec des matériaux imitant la pêche et la capture des écrevisses, e.g. trappes, cordes, filets, etc. Les désinfectants testés étaient le Proxitane ${ }^{\circledR} 5: 14$, le Proxitane ${ }^{\circledR} 12: 20$, le Wofasteril ${ }^{\circledR} E 400$, le Virkon ${ }^{\circledR} S$ et le peroxyde d'hydrogène. Les effets des produits chimiques ont été initialement testés dans des cultures de zoospores liquides et les concentrations efficaces ont ensuite été testées en utilisant des matériaux modèles propres et sales (feuille de PP, corde de nylon, tissu de coton) contaminés par des solutions de spores d'A. astaci. Les désinfectants efficaces contre les spores infectieuses de peste des écrevisses avec des matériaux modèles à la fois propres et sales étaient le Proxinate ${ }^{\circledR} 5: 14$ (concentration effective de $30 \mathrm{mg} \cdot \mathrm{L}^{-1}$ de PAA) et le Virkon ${ }^{\circledR} \mathrm{S}\left(3 \mathrm{~g} \cdot \mathrm{L}^{-1}\right)$, alors que le Proxinate ${ }^{\circledR} 12: 20$ (10 mg. $\mathrm{L}^{-1}$ de PAA) et le Wofasteril ${ }^{\circledR} \mathrm{E} 400$ (30 mg. $\mathrm{L}^{-1}$ de PAA) n'étaient efficaces que sur les matériels propres. Le peroxyde d'hydrogène n'était pas efficace dans

(1) The Department of Biology, University of Eastern Finland, Kuopio Campus, P.O. Box 1627, 70211 Kuopio, Suomi-Finland

* Corresponding author: japo.jussila@uef.fi 
les concentrations et les conditions testées. Sur la base de ces résultats, les désinfectants les plus appropriés pour la désinfection du matériel de pêche et de manipulation d'écrevisses seraient le Proxitane ${ }^{\circledR} 5: 14$ et le Virkon ${ }^{\circledR}$ S, à condition que tout le matériel ait été nettoyé à fond de la matière organique pour assurer l'inactivation des spores d'A. astaci.

\section{INTRODUCTION}

One of the main means of unintentional spreading of the Aphanomyces astaci spores is with infected fishing and crayfishing gear, such as nets, traps and cages (Matthews and Reynolds, 2002; Alderman, 1996; Oidtmann et al., 2002; Souty-Grosset et al., 2006) with the possibility of the interaction between different $A$. astaci strains increasing the potential threat (Makkonen et al., 2012; Jussila et al., 2013b). The virulence of the most common A. astaci isolates in Europe has been shown to be high and variable (Makkonen, 2013; Filipova et al., 2013; Jussila et al., 2013a) emphasising the need for the prevention of the spread of this disease. The European water courses are plentiful with most of them having an easy access. In addition to the fishing rights owners moving their gear from one water course to another, there are several fishermen being unaware of consequences of their fishing gear, not being properly disinfected, carrying several parasites and pathogens capable of infecting fauna in the target waters. The spreading of alien pathogens and even alien species has thus been assisted by fishermen not knowing the consequences of their actions.

Observations on the longevity of the various life stages of $A$. astaci have been presented (Svensson and Unestam, 1975). The authors observed that $A$. astaci cysts survived for 2 weeks in distilled water and that zoospores remained motile for up to 3 days (Unestam, 1969). As $A$. astaci can go through three cycles of zoospore emergence, the maximum life span outside of a host could be several weeks. Unestam (1966) found still viable spores in a spore suspension kept at $2{ }^{\circ} \mathrm{C}$ for 2 months. The described $A$. astaci stamina requires efficient disinfection methods.

Recently, EU level policies and strategic decisions have focused on the enhancement of biodiversity and prevention of the spread of alien species (EU, 2013). Some of the national alien species strategies list the disinfection of the material been transported among water systems as one of the key means in the prevention of disease spreading and conservation of the native species (e.g. MMM, 2013). In case of the native European crayfish, especially in the Nordic countries, where crayfish trapping is commonplace (Jussila and Mannonen, 2004), the crayfishing gear disinfection is of utmost importance. Easily available and practical to use disinfectants would also assist in the conservation of the native crayfish in Continental Europe. Furthermore, routine disinfection of stocking material and its transport water would be beneficial (Jussila et al., 2011; Kouba et al., 2012).

So far, easy and inexpensive means to disinfect the fishing and the crayfishing gear have been hard to obtain (e.g. Oidtmann et al., 2002) and some of the effective disinfectants have been banned or are outright hazardous, e.g. malachite green and formaldehyde (Marchand et al., 2012; Pedersen et al., 2007). The practical means to disinfect crayfishing and fishing gear include freezing, drying and heating (e.g. Alderman, 2000). Recently, there have been several papers published describing peracetic acid (PAA) based disinfectants (Koivunen and Heinonen-Tanski, 2005; Jussila et al., 2011; Pedersen et al., 2009, 2013; Kouba et al., 2012), which are easy to use, efficient in inactivation of also aquatic pathogens and, if not harmless to humans, then relatively safe to use.

The inactivation of aquatic animal pathogens by PAA based chemical solutions has been proven (Lilley and Inglis, 1997; Bugge, 2001; Weitkamp et al., 2007; Marchand et al., 2012), including its efficiency against crayfish plague spores (Jussila et al., 2011) and safety for crayfish (Kouba et al., 2012). The concentrations needed for A. astaci inactivation appear rather harmless for humans under practical disinfection conditions (Jussila et al., 2011) and 
Table I

The tested disinfectants and their proximate content. Further details in the material safety data sheets of the compound in question.

\begin{tabular}{|c|c|c|c|c|c|}
\hline & Wofaster $\|^{(B)} E 400$ & Proxitane ${ }^{(B)} 5: 14$ & Proxitane $\left.{ }^{(}\right) 12: 20$ & Virkon ${ }^{(B)} \mathrm{S}$ & $\begin{array}{l}\text { Hydrogen } \\
\text { peroxide }\end{array}$ \\
\hline $\begin{array}{l}\text { Effective } \\
\text { compound }\end{array}$ & PAA $40 \%$ & PAA $5 \%$ & PAA $12 \%$ & \begin{tabular}{|c} 
potassium \\
peroximonosulphate \\
$21.4 \%$
\end{tabular} & \begin{tabular}{|c|} 
Hydrogen \\
peroxide
\end{tabular} \\
\hline Formula & $\mathrm{C}_{2} \mathrm{H}_{4} \mathrm{O}_{3}$ & $\mathrm{C}_{2} \mathrm{H}_{4} \mathrm{O}_{3}$ & $\mathrm{C}_{2} \mathrm{H}_{4} \mathrm{O}_{3}$ & $\mathrm{H}_{3} \mathrm{~K}_{5} \mathrm{O}_{18} \mathrm{~S}_{4}$ & $\mathrm{H}_{2} \mathrm{O}_{2}$ \\
\hline \begin{tabular}{|l|} 
Other \\
compounds \\
in the solution
\end{tabular} & $\begin{array}{l}\text { hydrogen } \\
\text { peroxide, } \\
\text { acetic acid }^{1}\end{array}$ & \begin{tabular}{|c|} 
hydrogen \\
peroxice $15 \%$, \\
acetic acid $15 \%$
\end{tabular} & \begin{tabular}{|c|} 
hydrogen \\
peroxide $20 \%$, \\
acetic acid $20 \%$
\end{tabular} & $\begin{array}{c}\text { sodium } \\
\text { chlorine } 1.5 \%\end{array}$ & - \\
\hline $\begin{array}{l}\text { Breakdown } \\
\text { products }\end{array}$ & $\begin{array}{l}\text { Oxygen and } \\
\text { acetic acid }\end{array}$ & $\begin{array}{l}\text { Oxygen and } \\
\text { acetic acid }\end{array}$ & $\begin{array}{l}\text { Oxygen and } \\
\text { acetic acid }\end{array}$ & $\mathrm{N} / \mathrm{A}^{2}$ & $\begin{array}{l}\text { Oxygen } \\
\text { and } \\
\text { hydrogen }\end{array}$ \\
\hline
\end{tabular}

1 = manufacturer provides only PAA concentration; 2 = manufacturer does not provide the data .

the neutralisation after the disinfection process is simple (e.g. Pedersen et al., 2013). Currently there are several commercial PAA based disinfectants available in Europe, as these compounds have been routinely used for water purification (Koivunen and Heinonen-Tanski, 2005). This allows their usage, if proven effective in crayfish plague inactivation, to be routine also when disinfecting fishing and crayfishing gear. The opportunity to use these commercial disinfectants is beneficial, but their effectiveness under practical conditions against crayfish plague $(A$. astaci) spores has not been tested.

The aim of the study was to test the effect of selected commercial or common chemical disinfectants in inactivation of the crayfish plague spores under practical conditions. Based on the results we give recommendations for the chemicals to be utilised in prevention of the spread of $A$. astaci with water used in fish transport or being attached to fishing and crayfishing gear.

\section{MATERIALS AND METHODS}

\section{> PRODUCTION OF THE APHANOMYCES ASTACI SPORES}

The high virulent $A$. astaci isolate UEF8866-2 (Psl-genotype) from Lake Puujärvi (Makkonen et al., 2012), maintained in PG1 agar (Unestam, 1965), was used in the zoospore production. Zoospores were produced according the method described by Cerenius et al. (1988) with sterile Lake Kallavesi water washing steps. Zoospore production was made aseptically in $2 \mathrm{~mL}$ volume of PG1 media using 12-well plates, as described by Jussila et al. (2011). Zoospore concentrations were estimated in Bürker chamber and approximately 36000 zoospores and 67000 zoospores per replicate were used in the first and second test, respectively.

\section{> THE DISINFECTANTS AND MODEL MATERIALS}

The PAA based disinfectants were selected for evaluation based on easy availability and safety both for the user and for the environment. Wofasteril ${ }^{\circledR} 400$ contains $40 \%$ of peracetic acid (PAA), Proxitane ${ }^{\circledR 5}$ :14 contains $5 \%$ of PAA and Proxitane ${ }^{\circledR 1} 12: 20$ contains $12 \%$ of PAA with all of them having hydrogen peroxide and acetic acid as stabilising components (Table I). The breakdown products of PAA based disinfectants are rather harmless in practical concentrations, as are hydrogen peroxide's, too. Virkon ${ }^{\circledR} S$ has potassium peroximonosulphate $(21.4 \%)$ and sodium chlorine $(1.5 \%)$ as active ingredients. Commercial hydrogen peroxide's strength is $30 \%$.

We used a $2 \times 2 \mathrm{~cm}$ piece of plain polypropylene (PP) sheet as a model of modern traps, $2 \mathrm{~cm}$ intertwined nylon rope $(\varnothing 2 \mathrm{~mm}$ ) as a model of ropes and lines and $2 \times 2 \mathrm{~cm}$ piece 
Table II

Organic matter attached to the dirty model materials as proportional and absolute weight. PP refers to polypropylene.

\begin{tabular}{|l|c|c|c|c|c|c|}
\cline { 2 - 7 } \multicolumn{1}{c|}{} & \multicolumn{3}{c|}{ Proportional quantity (\%) } & \multicolumn{3}{c|}{ Absolute quantity (mg) } \\
\cline { 2 - 7 } \multicolumn{1}{c|}{} & Cotton fabric & Nylon rope & PP & Cotton fabric & Nylon rope & PP \\
\hline Mean & 22 & 10 & 1 & 10.4 & 3.6 & 1.3 \\
\hline SD & 9 & 4 & 1 & 5.4 & 1.7 & 1.2 \\
\hline Min & 13 & 6 & 0 & 5.4 & 2.2 & 0.7 \\
\hline Max & 32 & 16 & 3 & 17.2 & 5.7 & 3.0 \\
\hline
\end{tabular}

of cotton fabric as a model of other porous organic materials, including traditional mesh or wooden traps. The model materials were tested in triplicate as clean and dirty. The model materials tested as dirty were kept in an organic solution, obtained from the bottom sediment of Lake Kallavesi (Kuopio, Finland), for one week in the room temperature $\left(18^{\circ} \mathrm{C}\right)$ for the organic matter to attach on their surface to imitate the outcome of the fishing and crayfishing gear been used before disinfection. Then the materials were dried in oven $\left(60{ }^{\circ} \mathrm{C}\right)$ for $16 \mathrm{~h}$ and sterilized by autoclaving in $5 \mathrm{~mL}$ test tubes. In order to determine the amount of organic material attached to model materials, they were weighed before and after sediment treatment. The amount of organic matter varied, with cotton fabric having the highest proportion and absolute quantity of organic matter (Table II), the nylon rope being the second dirtiest and the piece of hard PP being the cleanest.

\section{> EFFECTIVE CONCENTRATIONS IN IN VITRO SUSPENSIONS}

The efficacy of disinfection chemical was first evaluated in 96 well plates using A. astaci spore suspension. Two individual tests were done using following chemicals: Wofasteril ${ }^{\circledR} E 400$, Virkon ${ }^{\circledR} S$ and hydrogen peroxide (1st test) and Proxinate ${ }^{\circledR} 5: 14$, Proxinate ${ }^{\circledR} 12: 20$, Wofasteril ${ }^{\circledR} E 400$ and Virkon ${ }^{\circledR} S$ (2nd test). The tested concentrations were planned and adjusted according to the specifications on the usage of the commercial solutions and our previous results (Jussila et al. 2011). The tested PAA and hydrogen peroxide $\left(\mathrm{H}_{2} \mathrm{O}_{2}\right)$ concentrations were $0.04,0.1,0.4,1.1,3.3,10$ and $30 \mathrm{mg} \cdot \mathrm{L}^{-1}$ and Virkon ${ }^{\circledR} \mathrm{S}$ concentrations were $0.01,0.04,0.12,0.4,1.1,3.3$ and $10 \mathrm{mg} \cdot \mathrm{L}^{-1}$ of Virkon ${ }^{\circledR} \mathrm{S}$. All the treatments were done in triplicate and sterilized MilliQ water was used as a control.

In the first test, a $100 \mu \mathrm{L}$ volume of spore suspension was mixed with $100 \mu \mathrm{L}$ of disinfectant solution or control water. After $10 \mathrm{~min}$ and $30 \mathrm{~min}$ incubation, $90 \mu \mathrm{L}$ samples ( 460 spores) were taken and added to $100 \mu \mathrm{L}$ of PG1 culture media in 96 well plates. The second test was done similarly to the first one except that $100 \mu \mathrm{L}$ samples ( 450 spores) were taken after 15 min disinfection treatment and mixed with $100 \mu \mathrm{L}$ of PG1 culture media. Liquid cultures were observed for eight and ten weeks, in the first and the second test, respectively.

\section{> EFFECT OF THE DISINFECTANTS WITH THE MODEL MATERIALS}

Disinfection tests with model materials were done in $5 \mathrm{~mL}$ test tubes in duplicates. Selected chemicals were first tested using PAA concentrations of 2 and $6 \mathrm{mg} \cdot \mathrm{L}^{-1}$ for Wofasteri ${ }^{\circledR} \mathrm{E} 400$, Proxitane ${ }^{\circledR} 5: 14$ and Proxitane ${ }^{\circledR} 12: 20$ and 0.1 and $0.3 \mathrm{~g} \cdot \mathrm{L}^{-1}$ of Virkon ${ }^{\circledR} \mathrm{S}$. In the second test, concentrations were 10 and $30 \mathrm{mg} \cdot \mathrm{L}^{-1}$ of PAA for Wofasteril ${ }^{\circledR} \mathrm{E} 400$, Proxitane ${ }^{\circledR} 5: 14$ and Proxitane ${ }^{\circledR} 12: 20$ and 1.0 and $3.0 \mathrm{~g} \cdot \mathrm{L}^{-1}$ of Virkon ${ }^{\circledR} \mathrm{S}$.

Sterile, autoclaved test materials, both clean and dirty treatment, were incubated in $2 \mathrm{~mL}$ of spore suspension in $20^{\circ} \mathrm{C}$ for one day to enable zoospores to attach to the test materials. For disinfection, spore suspensions were removed and materials were treated with $4 \mathrm{~mL}$ of disinfectants with the materials fully submerged. After 15 min incubation disinfectants were removed and $2 \mathrm{~mL}$ of PG1 culture media was added. In the first and second test, liquid cultures were monitored for three and six weeks, respectively. 


\section{Table III}

The concentrations required for the inactivation of crayfish plague (A. astaci) spores. Tested and efficient commercial disinfectants brands are PAA-based and Virkon ${ }^{\circledR}$ S. Concentrations are expressed as $g$ of Virkon ${ }^{\circledR} S$ in to solution or mg of PAA in the solution. Results from 10 min and 30 min experiments were similar and thus the results are combined. Spore growth expressed as $-=$ no detection of growth, $+=$ growth detected.

\begin{tabular}{|c|c|c|c|c|c|}
\hline \multicolumn{2}{|c|}{ Virkon ${ }^{(B)}$} & \multicolumn{2}{|c|}{ Wofasteri ${ }^{\mathbb{B}} 400$} & \multicolumn{2}{|c|}{ Proxitane ${ }^{(\mathbb{R})} 5: 14$, Proxitane $e^{(\mathbb{})} 12-20$} \\
\hline $\mathrm{g} \cdot \mathrm{L}^{-1}$ & Spore growth & PAA, $m g \cdot L^{-1}$ & Spore growth & PAA, $m g \cdot L^{-1}$ & Spore growth \\
\hline 10.00 & - & 30.00 & - & 30.00 & - \\
\hline 3.30 & - & 10.00 & - & 10.00 & - \\
\hline 1.10 & - & 3.30 & + & 3.30 & - \\
\hline 0.40 & - & 1.10 & + & 1.10 & + \\
\hline 0.12 & - & 0.40 & + & 0.40 & + \\
\hline 0.04 & + & 0.10 & + & 0.10 & + \\
\hline 0.01 & + & 0.04 & + & 0.04 & + \\
\hline
\end{tabular}

\section{Table IV}

The PAA concentrations effective for the inactivation of $A$. astaci spores in model materials. The underlined and bold concentrations were chosen as effective at this stage. Remarks: $n / e=$ not effective $P P=$ polypropylene and 1 = result based on the first test.

\begin{tabular}{|c|c|c|c|c|}
\hline & $\begin{array}{c}\text { Virkon }{ }^{(8) S} \\
\text { g. L }{ }^{-1}\end{array}$ & $\begin{array}{c}\text { Proxitane }{ }^{(\Theta)} 5: 14 \\
\mathrm{mg} \cdot \mathrm{L}^{-1}\end{array}$ & $\begin{array}{c}\text { Wofasteri }[(\mathbb{B}) \equiv 400 \\
\mathrm{mg} \cdot \mathrm{L}^{-1}\end{array}$ & $\begin{array}{c}\text { Proxitane }{ }^{(8)} 12: 20 \\
\mathrm{mg} \cdot \mathrm{L}^{-1}\end{array}$ \\
\hline \multicolumn{5}{|l|}{ Clean material } \\
\hline $\mathbf{P P}^{1}$ & 0.1 & 2 & 2 & 2 \\
\hline Nylon rope & 1.0 & 10 & $\underline{30}$ & 10 \\
\hline Cotton fabric & 1.0 & 10 & 10 & $\underline{10}$ \\
\hline \multicolumn{5}{|l|}{ Dirty material } \\
\hline PP & 1.0 & 30 & 30 & $n / e$ \\
\hline Nylon rope & 1.0 & 30 & $n / e$ & $n / e$ \\
\hline Cotton fabric & $\underline{3.0}$ & $\underline{30}$ & $n / e$ & $n / e$ \\
\hline
\end{tabular}

\section{RESULTS}

\section{> EFFECTIVE CONCENTRATIONS IN IN VITRO SUSPENSION}

The spore germination and growth in PG1 culture media was successfully inhibited by using PAA based chemicals and Virkon ${ }^{\circledR} S$, but the hydrogen peroxide did not inactivate the spores in any of the tested concentrations within the monitoring time and was thus left out of the further practical tests. Virkon ${ }^{\circledR} \mathrm{S}$ was effective at the dose of $0.12 \mathrm{~g} \cdot \mathrm{L}^{-1}$ of Virkon ${ }^{\circledR} \mathrm{S}$ (Table III) and the effective PAA concentration was $10 \mathrm{mg} \cdot \mathrm{L}^{-1}$ for Wofasteril ${ }^{\mathbb{B}} \mathrm{E} 400$ while lower concentration, i.e. $3.3 \mathrm{mg} \cdot \mathrm{L}^{-1}$, for other PAA based chemicals was sufficient (Table III). The different levels of hydrogen peroxide or acetic acid, the stabilising components in different PAA based solutions, did not alter the effective PAA concentration in vitro.

Based on these results, a minimum dose for the following model material disinfection test for Virkon ${ }^{\circledR} \mathrm{S}$ was $0.1 \mathrm{~g} \cdot \mathrm{L}^{-1}$ and for PAA based chemicals $2 \mathrm{mg} \cdot \mathrm{L}^{-1}$ of PAA.

\section{> EFFECT OF THE DISINFECTANTS WITH MODEL MATERIALS}

After six weeks of the follow-up, spore inactivation was $100 \%$ in all tested clean and dirty materials for Virkon ${ }^{\circledR} S$ at selected concentrations of 1 and $3 \mathrm{~g} \cdot \mathrm{L}^{-1}$, except for dirty cotton fabric, for which model material only $3 \mathrm{~g} \cdot \mathrm{L}^{-1}$ was effective (Table IV). For solutions containing PAA, both 10 and $30 \mathrm{mg} \cdot \mathrm{L}^{-1}$ of PAA resulted in $100 \%$ inactivation in all clean materials, with the exception that with Wofasteril ${ }^{\mathbb{E}} \mathrm{E} 400$ at a concentration of $10 \mathrm{mg} \cdot \mathrm{L}^{-1}$ of PAA one of the plastic rope replicates showed hyphal growth. Even though the growth appeared atypical for A. astaci hyphae, the $10 \mathrm{mg} \cdot \mathrm{L}^{-1}$ of PAA concentration was considered a failure in inactivation. With the dirty materials, only Proxitane ${ }^{\circledR} 5: 14$ at the concentration of $30 \mathrm{mg} \cdot \mathrm{L}^{-1}$ of PAA resulted in $100 \%$ inactivation. 


\section{DISCUSSION}

We have shown that several commercial disinfectants can be used for inactivation of crayfish plague ( $A$. astaci) spores attached to tested model fishing or crayfishing gear. Two of the tested different chemical formulations were effective in practical concentrations even when the tested material was covered with organic matter, as might be the case under practical situations. We would still recommend that prior to the disinfection, and regardless the effectiveness of the disinfectants shown in this study, the material should be rinsed or even cleaned of the organic matter to enhance to power of the disinfectants on the crayfish plague spores (e.g. Alderman and Polglase, 1985; Pedersen et al., 2013).

We showed that peracetic acid based disinfectant Proxitane ${ }^{\circledR} 5: 14$ at the PAA concentration of $30 \mathrm{mg} \cdot \mathrm{L}^{-1}$ and Virkon ${ }^{\circledR} \mathrm{S}$ at the concentration of $3 \mathrm{~g} \cdot \mathrm{L}^{-1}$ of Virkon ${ }^{\circledR} \mathrm{S}$ were effective. The recommended concentrations are slightly higher than the lowest effective concentrations for clean material and would thus allow the disinfected material to be covered in organic matter, normally accumulating on the fishing and crayfishing gear surfaces when they are in use. We also showed, that two other PAA based disinfectants would be effective at a concentration of $30 \mathrm{mg} \cdot \mathrm{L}^{-1}$ providing that the disinfected gear would be thoroughly cleaned.

These findings are similar with our previous findings on the effect of the PAA on crayfish plague spores in aquaculture conditions (Jussila et al., 2011). The concentrations found effective in this study are higher than those recommended for fish aquaculture against Ichthyophthirius multifiliis (Rintamäki-Kinnunen et al., 2005a, 2005b). It has previously been shown that crayfish seem to tolerate higher concentrations of the PAA than fish (Jussila et al., 2011; Kouba et al., 2012) and we even observed indications of improved survival of the crayfish been bathed using PAA (Jussila et al., 2011). The PAA concentrations found effective in the disinfection of the fishing or crayfishing material in this study are too high for fish under aquaculture conditions.

The effect of the PAA based disinfectant solutions may not depend only on the PAA concentration itself, but acetic acid and hydroxen peroxide may have adjusted the $\mathrm{pH}$, affected the PAA kinetics and its efficiency. Thus, Proxitane ${ }^{\circledR} 5: 14$ was effective in A. astaci spore inactivation even when the model materials were carrying a load of organic matter, in which situation the other tested PAA based disinfectants failed. We assume that these additional chemicals, i.e. hydrogen peroxide and acetic acid, assisted in slowing down the breakdown of PAA and thus improving Proxitane ${ }^{\circledR} 5: 14$ 's efficiency against the pathogens. The matter is interesting and might require further studies.

The suggested concentrations of PAA for $A$. astaci inactivation are rather high, and exceed those found harmless for aquatic animals, such as fish (Meineilt et al., 2007; Rintamäki-Kinnunen et al., 2005a, 2005b) and biofilm microbes and planktonic organisms (Pedersen et al., 2013), sometimes causing problems in aquaculture. Thus, as has been reported before (Jussila et al., 2011), these concentrations could not be used in the aquaculture systems together with fish. The LC50 96h for PAA against adult and one year old signal crayfish (P. leniusculus) has been shown to be $>70 \mathrm{mg} \cdot \mathrm{L}^{-1}$ (Kouba et al., 2012), which is in line with our observations (unpublished data), while the early juveniles are more susceptible to PAA with LC50 $96 \mathrm{~h}$ of $15 \mathrm{mg} \cdot \mathrm{L}^{-1}$. Thus the recommended PAA concentrations could also be used in the crayfish aquaculture systems, in preventing the spread of disease agents attached to the surfaces when stocking farmed crayfish, but further studies are needed to verify this matter.

We also detected that Virkon ${ }^{\circledR} \mathrm{S}$, a different chemical formulation, could be used for the disinfection of the fishing and crayfishing gear. This disinfectant proved effective also for the material loaded with organic matter, e.g. sedimented fine particle matter, in the concentration of $3 \mathrm{~g} \cdot \mathrm{L}^{-1}$ of Virkon ${ }^{\circledR} \mathrm{S}$. This concentration is lower than the recommendation by the manufacturer, i.e. $10 \mathrm{~g} \cdot \mathrm{L}^{-1}$, which should be the minimum amount being used under practical conditions. Regardless of the shown inactivation even with the dirty model material for the $3 \mathrm{~g} \cdot \mathrm{L}^{-1}$ of Virkon ${ }^{\circledR} \mathrm{S}$, our recommendation for also Virkon ${ }^{\circledR} \mathrm{S}$ usage is that all disinfected material should be carefully rinsed to remove excess organic matter. 
The tested PAA based disinfectants could be disposed of after they have been neutralized or have broken down during disinfection process. A practical manner to neutralise PAA based disinfectants is to add organic matter or salt to the solution after the disinfection (e.g. Pedersen et al., 2013). This would exhaust the oxidising potential of the PAA based solution and thus it could be disposed of safely.

As the prevention of the accidental spread of the crayfish plague in fishing and crayfishing gear is of utmost importance (Oidtmann et al., 2002; Kouba et al., 2012; Jussila et al., 2013a, 2013b), we summarise that certain peracetic acid (PAA) based solutions would be suitable for the disinfection of the fishing and crayfishing gear. The benefit of PAA based solution as a disinfectant is that the breakdown compounds are rather harmless to the environment and humans, too, thus increasing work safety. We also found Virkon ${ }^{\circledR} S$ to be effective, but maybe not as suitable for the practical layman conditions as solutions containing PAA.

\section{ACKNOWLEDGEMENTS}

The study was funded by Northern Savo Centre for Economic Development, Transport and the Environment, resources from the European Fisheries Fund, as the EU invests in sustainable fisheries. The authors wish to thank the participants of the IAA 19 conference Crayfish Plague Workshop in Innsbruck (Austria) for the discussions leading to the selection of the chemical compounds to be tested. The authors are not recommending any of the commercial brands and those tested in this experiment are only to be taken as examples of the disinfectants commonly available. LIFE+ RapuKamu project has acted as a innovative motivator of this study.

\section{REFERENCES}

Alderman D.J., 1996. Geographical spread of bacterial and fungal diseases of crustaceans. Rev. Sci. Tech., 15, 603-632.

Alderman D.J., 2000. Summary final report: effects of exposure to high and low temperatures on the survival of the crayfish plague fungus $A$. astaci in vitro and in vivo. Australian Quarantine and Inspection Service, Canberra, Australia.

Alderman D.J. and Polglase J.L., 1985. Disinfection for crayfish plague. Aquacult. Fish. Manag., 16, 203-205.

Bugge, E., 2001. Disinfectant and method for control of parasites. Patent No. WO2001062090.

Cerenius L., Söderhäll K., Persson M. and Ajaxon, R., 1988. The crayfish plague fungus Aphanomyces astaci - diagnosis, isolation, and pathobiology. Freshw. Crayfish, 7, 131-144.

EU, 2013. Invasive alien species. http://ec.europa.eu/environment/nature/invasivealien/. Visited 151013.

Filipová L., Petrusek A., Matasová K., Delaunay C. and Grandjean F., 2013. Prevalence of the Crayfish Plague Pathogen Aphanomyces astaci in Populations of the Signal Crayfish Pacifastacus leniusculus in France: Evaluating the Threat to Native Crayfish. PLoS ONE, 8, e70157.

Jussila J. and Mannonen A., 2004. Crayfisheries in Finland, a short overview. Bull. Fr. Pêche Piscic., 372-373, 263-273.

Jussila, J., Makkonen J. and Kokko H., 2011. Peracetic acid (PAA) treatment is an effective disinfectant against crayfish plague (Aphanomyces astaci) spores in aquaculture. Aquaculture, 320, 37-42.

Jussila, J., Kokko H., Kortet R. and Makkonen J. 2013a. Aphanomyces astaci Psl-genotype isolates from different Finnish signal crayfish stocks show variation in their virulence but still kill fast. Knowl. Manag. Aquatic Ecosyst., 411, 10.

Jussila, J., Makkonen J., Vainikka A., Kortet R. and Kokko H., 2013b. Crayfish plague dilemma: how to be a corteous killer? Boreal Environ. Res., in print.

Koivunen, J. and Heinonen-Tanski H., 2005. Peracetic acid (PAA) disinfection of primary, secondary and tertiary treated municipal wastewaters. Water Res., 39, 4445-4453. 
Kouba A., Kuklina I., Niksirat H., Máchová J. and Kozák P., 2012. Tolerance of signal crayfish (Pacifastacus leniusculus) to Persteril 36 supports use of peracetic acid in astaciculture. Aquaculture, 350-353, 71-74.

Lilley, J.H. and Inglis V., 1997. Comparative effects of various antibiotics, fungicides and disinfectants on Aphanomyces invaderis and other saprolegniaceous fungi. Aquacult. Eng., 28, 461-469.

Makkonen J., 2013. The crayfish plague pathogen Aphanomyces astaci. Genetic diversity and adaptation to the host species, Doctoral dissertation, University of Eastern Finland.

Makkonen, J., Jussila J. and Kokko H., 2012. The diversity of the pathogenic Oomycete (Aphanomyces astaci) chitinase genes within the genotypes indicate adaptation to its hosts. Fungal Gen. Biol., 49, 635-642.

Marchand P.-A., Phan T.-M., Straus D.L., Farmer B.D., Stüber A. and Meinelt T., 2012. Reduction of in vitro growth in Flavobacterium columnare and Saprolegnia parasitica by products containing peracetic acid. Aquac. Res., 43, 1861-1866.

Matthews M.A. and Reynolds J.D. 1992. Ecological impact of crayfish plague in Ireland. Hydrobiol., 254, $1-6$.

Meineilt, T., Richert I., Stuber A. and Braunig I., 2007. Anti-parasitic effects of peracetic acid (PAA) to free infective stages (Theronts) of the white spot disease, Ichthyophthirius multifilis in vitro. Deut. Tierarzl. Woch., 114, 384-387.

MMM, 2013. Alien species in Finland. http://www.mmm.fi/en/index/frontpage/natural_resources/ invasive_alien_species.html. Visited 151031.

Oidtmann, B., Heitz E., Rogers D. and Hoffmann R.W., 2002. Transmission of crayfish plague. Dis. Aquat. Organ., 52, 159-167.

Pedersen, L.-F., Pedersen P.B. and Sortkjær O., 2007. Temperature-dependent and surface specific formaldehyde degradation in submerged biofilters. Aquacult. Eng., 36, 127-136.

Pedersen, L.-F., Pedersen P.B., Nielsen J.L. and Nielsen P.H., 2009. Peracetic acid degradation and effects on nitrification in recirculating aquaculture systems. Aquaculture, 296, 246-254.

Pedersen, L.-F., Meinelt T. and Straus D.L., 2013. Peracetic acid degradation in freshwater aquaculture systems and possible practical implications. Aquacult. Eng., 53, 65-71.

Rintamäki-Kinnunen P., Rahkonen M., Mannermaa-Keränen A.L., Suomalainen L.R., Mykrä H. and Valtonen E.T., 2005a. Treatment of ichthyophthiriasis after malachite green. I. Concrete tanks at salmonid farms. Dis. Aquat. Organ., 64, 69-76.

Rintamäki-Kinnunen P., Rahkonen M., Mannermaa-Keränen A.L., Suomalainen L.R., Mykrä H. and Valtonen E.T., 2005b. Treatment of ichthyophthiriasis after malachite green II. Earth ponds at salmonid farms. Dis. Aquat. Organ., 66, 15-20.

Souty-Grosset C., Holdich D.M., Noël P.Y., Reynolds J.D. and Haffner P., 2006. Atlas of crayfish in Europe, Muséum national d'Histoire naturelle, Paris, 187 p.

Svensson E. and Unestam T., 1975. Differential induction of zoospore encystment and germination in Aphanomyces astaci, Oomycetes. Physiol. Plantarum, 35, 210-216.

Unestam T., 1965. Studies on the crayfish plague fungus Aphanomyces astaci I. Some factors affecting growth in vitro. Physiol. Plantarum, 18, 483-505.

Unestam T., 1966. Studies on the crayfish plague fungus Aphanomyces astaci II. Factors affecting zoospores and zoospore production. Physiol. Plantarum, 19, 1110-1119.

Unestam T., 1969. On the adaptation of Aphanomyces astaci as a parasite. Physiol. Plantarum, 22, 221-235.

Weitkamp, H., Meinelt T., Bräunig I., Staaks J. and Jander G., 2007. Einsatz von Peressigsäure bei FischEktoparasitosen. Tagungsband XI. Gemeinschaftstagung der Deutschen, der Österreichischen und der Schweizer Sektion der European Association of Fish Pathologists: 11-13 October 2006, Murten, Switzerland, pp. 1-21. 